\title{
Lack of association between PRNP M129V polymorphism and multiple sclerosis, mild cognitive impairment, alcoholism and schizophrenia in a Korean population
}

\author{
Ihn-Geun Choi ${ }^{\mathrm{a}, 1}$, Sung-Il Woo ${ }^{\mathrm{b}, 1}$, Ho Jin Kim ${ }^{\mathrm{c}, 1}$, Dai-Jin Kim ${ }^{\mathrm{d}, 1}$, Byung Lae Park ${ }^{\mathrm{e}, 1}$, \\ Hyun Sub Cheong ${ }^{e}$, Charisse Flerida A. Pasaje ${ }^{f}$, Tae Joon Park ${ }^{\mathrm{f}}$, Joon Seol Bae ${ }^{\mathrm{f}}$, Young Gyu Chai ${ }^{\mathrm{g}}$ and \\ Hyoung Doo Shin ${ }^{\mathrm{e}, \mathrm{f}, *}$ \\ ${ }^{a}$ Department of Neuropsychiatry, Hallym University, Han-Gang Sacred Heart Hospital, Seoul, Korea \\ ${ }^{\mathrm{b}}$ Department of Neuropsychiatry, Soonchunhyang University Hospital, Seoul, Korea \\ ${ }^{\mathrm{c}}$ Department of Neurology, National Cancer Center, Gyeonggi-do, Korea \\ ${ }^{\mathrm{d}}$ Department of Psychiatry, Holy Family Hospital, College of Medicine, Catholic University of Korea, Korea \\ e Department of Genetic Epidemiology, SNP Genetics, Inc., WooLim Lion's Valley, Seoul, Korea \\ ${ }^{\mathrm{f}}$ Department of Life Science, Sogang University, Seoul, Korea \\ ${ }^{\mathrm{g}}$ Division of Molecular and Life Sciences, Hanyong University, Ansan, Korea
}

\begin{abstract}
The genetic variant at codon 129 (M129V) of the prion protein gene $(P R N P)$ is considered to be a major genetic risk factor for prion diseases. In this study, we examined the possible genetic association of $P R N P * 129 \mathrm{Val}$ with multiple sclerosis (MS, $n=681$ ), mild cognitive impairment (MCI, $n=801)$, alcoholism $(n=761)$ and schizophrenia $(n=715)$ in a Korean population, and compared the data with previous genetic association studies of the variant. The minor allele frequency of $P R N P * 129 \mathrm{Val}(\mathrm{MAF}=0.025)$ was significantly lower in Korean population $(n=2,479)$ compared to Caucasian populations $(\mathrm{P}$ $<0.0001$ ), suggestive of a weak influence of the variant in the previous population. Statistical analysis revealed no significant association between $P R N P^{*} 129 \mathrm{Val}$ and $\mathrm{MS}(\mathrm{P}=0.76)$, MCI $(\mathrm{P}=0.46)$, alcoholism $(\mathrm{P}=0.84)$ and schizophrenia $(\mathrm{P}=0.69)$. These findings were discussed in the context of prior inconsistent reports on the role of $P R N P * 129 \mathrm{Val}$ polymorphism in several diseases. Results from this study may provide further evidence that PRNP M129V is not a genetic susceptibility factor for MS, MCI, alcoholism and schizophrenia in a Korean population.
\end{abstract}

Keywords: Prion, PRNP M129V, multiple sclerosis, mild cognitive impairment, alcoholism, schizophrenia

\section{Introduction}

The methionine/valine polymorphism at codon 129 of the prion protein gene $(P R N P)$ have been known

\footnotetext{
${ }^{1}$ These authors have contributed equally to this work.

* Corresponding author: Dr. Hyoung Doo Shin, Department of Life Science, Sogang University, 1 Shinsu-dong, Mapo-gu, Seoul 121-742, Korea, 121-742. Tel.: +82 2705 8615; Fax: +82 22026 4299; E-mail: hdshin@sogang.ac.kr.
}

risk factors for clinical and pathologic phenotype of both sporadic and familial forms of prion diseases [13], such as Creutzfeldt-Jakob disease (CJD) [4,5], Gerstmann-Sträussler-Scheinker disease (GSS), fatal familial insomnia (FFI) [6-9], Alzheimer's disease (AD), and multiple sclerosis (MS) [10]. Interestingly, we were able to observe that results from earlier association studies involving M129V polymorphism do not correspond with the findings of more recent investigations, and therefore, we would like to contend that 
more comprehensive studies are necessary to reevaluate the current findings on PRNP*129Val, specifically with the following diseases: MS, mild cognitive impairment (MCI), alcoholism and schizophrenia.

In MS, the mechanism underlying this association can be traced to the modified prion as a factor initializing immune system reactions against myelin membrane of neuronal axons [11]. Although a previous study revealed basis for association between PRNP*129Val polymorphism and MS [10], a contrasting report that found no association with this variant has also been presented [12]. Similarly, findings on the influence of $P R N P * 129 \mathrm{Val}$ in the risk of $\mathrm{AD}$, another neurodegenerative disorder, have been well defined despite ethnic background discrepancies. Previous studies have reported that this variant is significantly associated with AD in Dutch [13], German [14], and Polish populations [15], in contrast to the findings from studies involving Korean [16], Spanish [17], and Italian [18] populations. Furthermore, it has been known that homozygosity for codon 129 (M or V allele) is connected with early-onset AD [13,17]. Mild cognitive impairment (MCI) is a transition stage between cognitive decline of normal aging and the complications of AD. The neuropathologic mechanisms in MCI are associated with progression to $\mathrm{AD}$ and the mood-related depressive symptoms in the preclinical stage of the disease [19, 20]. A previous report also showed that M129V polymorphisms are associated with reduced cognitive abilities in the elderly [21]. With the previous association studies reported on PRNP*129Val in MS, cognitive decline and $\mathrm{AD}$, there is, then a need to verify the role of this variant in MS and MCI.

The M129V polymorphism has also been a recognized genetic marker for susceptibility to CreutzfeldtJakob disease (CJD) [4,22,23]. Often correlated with this condition is a complication of alcoholism that causes thiamine deficiency and longer disease duration among patients [24,25]. Other than this, CJD and alcoholism are quite distinct clinically. However, at this stage it may be rewarding to analyze the influence of PRNP*129Val with alcoholism.

Since psychiatric manifestations appear in the early phase of CJD, it has been hypothesized that the prion protein could also be involved in psychiatric disorders such as schizophrenia. In fact, reports have suggested that neurodegenerative processes emerge in the earlyonset of schizophrenia spectrum disorders [26-28]. A previous study has demonstrated that methionine homozygosity at codon 129 is associated with a reduction in white matter tissue and a larger volume of cere- brospinal fluid in schizophrenic patients [29]. This is meaningful since negative symptoms of schizophrenia include low global white matter volumes and reductions in the white matter of the specific prefrontal cortex area [30]. However, a case-control-study conducted in Caucasian patients with Schizophrenia reported that the PRNP SNP does not contribute to the genetic susceptibility for the disease [31]. To further clarify the role of methionine as a susceptibility genetic factor for schizophrenia, an association study between $P R N P^{*} 129 \mathrm{Val}$ and the disease should be carried out.

In view of the above, we conducted an extensive investigation as to the function of $P R N P * 129 \mathrm{Val}$ in MS ( $n=681)$, MCI $(n=801)$, alcoholism $(n=761)$ and schizophrenia (SC, $n=715$ ) in a Korean population. Results from this study would provide further insights into the conflicting findings on the role of $P R N P * 129$ Val polymorphism in several neuropsychiatric diseases.

\section{Subjects, materials and methods}

Description of the study subjects has been reported in previous studies which vary only in the number of samples as summarized in: MS, MCI [32], alcoholism [33] and schizophrenia [34]. Briefly, the following subjects were included in the current study: 681 for the MS study (200 cases and 481 controls); 801 for the MCI study (320 cases and 481 controls); 761 for the alcoholism study (540 cases and 223 controls); and 715 for the schizophrenia study (348 cases and 367 controls). For MS and MCI studies, we used 481 shared controls consisted of healthy and old-age individuals of Korean ethnicity who, at the moment, were not diagnosed with MS and MCI. The control group for alcoholism composed of healthy male employees of Hangang Sacred Heart Hospital who were mostly non-drinkers as revealed by a drinking habit questionnaire. An exclusion criterion was having first-degree relatives with major psychiatric disorders. Similarly, healthy employees of Hangang Sacred Heart Hospital and Center for Health Promotion of Seoul National University Hospital made up the control group for schizophrenia association study. To ensure that the participants did not have an ongoing or previous psychiatric illness, each control subject was evaluated by a trained clinician using the Structured Clinical Interview for DSM-IV, non-patient edition (SCID-NP). This study incorporated large sample sizes for each studied group, which are most effective in detecting simple gene changes. The research 
Table 1

Association analysis of $P R N P$ M129V with neuropsychiatric diseases in a Korean population

\begin{tabular}{|c|c|c|c|c|c|}
\hline Disease & Genot & Case & Control* & OR & HWE \\
\hline \multirow{3}{*}{ Multiple sclerosis } & MM & $187(93.5 \%)$ & $455(94.6 \%)$ & & \\
\hline & MV & $13(6.5 \%)$ & $26(5.4 \%)$ & $1.28(0.27-6.19)$ & 0.76 \\
\hline & VV & $0(0.0 \%)$ & $0(0.0 \%)$ & & \\
\hline \multirow[t]{3}{*}{ Mild cognitive Impairment } & MM & $306(95.6 \%)$ & $455(94.6 \%)$ & & \\
\hline & MV & $14(4.4 \%)$ & $26(5.4 \%)$ & $0.76(0.36-1.57)$ & 0.46 \\
\hline & VV & $0(0.0 \%)$ & $0(0.0 \%)$ & & \\
\hline \multirow[t]{3}{*}{ Alcoholism } & MM & $514(95.2 \%)$ & $213(95.5 \%)$ & & \\
\hline & MV & $26(4.8 \%)$ & $10(4.5 \%)$ & $1.08(0.51-2.27)$ & 0.84 \\
\hline & VV & $0(0.0 \%)$ & $0(0.0 \%)$ & & \\
\hline \multirow[t]{3}{*}{ Schizophrenia } & MM & $329(94.5 \%)$ & $347(94.6 \%)$ & & \\
\hline & MV & $19(5.5 \%)$ & $19(5.2 \%)$ & $0.87(0.43-1.75)$ & 0.69 \\
\hline & VV & $0(0.0 \%)$ & $1(0.3 \%)$ & & \\
\hline
\end{tabular}

Logistic regression analyses were performed for odds ratios and corresponding $P$-value of the co-dominant model controlling for age (continuous value) and sex (male $=0$, female $=1$ ) as covariates.

OR: odds ratio; HWE: $P$-values of deviation from Hardy-Weinberg equilibrium.

*For association studies of mild cognitive impairment and multiple sclerosis, shared controls $(n=$ 481) were used for comparison.

protocols were approved by the Institutional Review Board of each hospital, and informed consents were obtained from each subject.

Genotyping of $P R N P^{*} 129 \mathrm{Val}$ polymorphism was performed using the TaqMan method [35]. To determine if the individual variants were in Hardy-Weinberg equilibrium, $\chi^{2}$ tests were carried out. Logistic regression analyses controlling for age as covariate were used to calculate odds ratios and $P$-values for case-control analysis.

\section{Results}

We genotyped 2,479 samples from our existing case/control studies of multiple sclerosis (cases/controls $=200 / 481$ ), mild cognitive impairment (cases/controls $=320 / 481)$, alcoholism $($ cases/controls $=540 / 223$ ) and schizophrenia (cases/controls = $348 / 367$ ). For association studies of mild cognitive impairment and multiple sclerosis, shared controls ( $n=$ 481) were used for comparison. Table 1 shows the allele and genotype frequencies. The genotype distributions in all studied groups were in Hardy-Weinberg equilibrium. Statistical analysis revealed no significant difference between the allele and genotype frequencies of the controls for each studied group and MS ( $\mathrm{P}=$ $0.76)$, MCI $(\mathrm{P}=0.46)$, alcoholism $(\mathrm{P}=0.84)$ and $\mathrm{SC}$ $(\mathrm{P}=0.69)$ in a Korean population. The minor allele frequency (MAF) of $P R N P^{*} 129 \mathrm{Val}$ in a Korean population $(n=2,816)$ was 0.026 .

A summary of $P R N P * 129 \mathrm{Val}$ frequency among different ethnic groups is presented in Table 2. The MAF of $P R N P * 129 \mathrm{Val}$ in Asian populations (freq. $=0.01-$ 0.03 ) is generally much lower than in Caucasian populations (freq. $=0.24-0.39)(\mathrm{P}<0.0001$, data not shown). Lastly, we showed a summary on worldwide genetic association studies of PRNP*129Val in Table 3.

\section{Discussion}

Genetic associations of $P R N P * 129 \mathrm{Val}$ with the risk of several diseases other than CJD are of interest but are still up for debate (Table 3). Several studies reported statistically significant association with this variant and $\mathrm{AD}$ [15], late-onset $\mathrm{AD}$ [36], early-onset AD $[13,37]$, temporal lobe epilepsy in an Italian population (TLE) [38], MS [10], and cognitive performance and impairment $[21,37,39]$, as opposed to studies that found no association with M129V polymorphism and Parkinson's disease (PD) [40,41], TLE in a Hans Chinese population [42] and MS [12]. Although it is hard to decipher the reason behind the discrepancies among previous studies on the effect of this important PRNP variant on neuropsychiatric diseases, the relatively low sample sizes (cases or controls) and/or marginal significances in previous studies could be plausible explanations. In addition, the large difference in frequency between Asian populations (freq. $=0.02-0.03$ ) and Caucasian populations (freq. $=0.24-0.39$ ) may also influence the previous results.

The mechanisms underlying the association between MS and schizophrenia and $P R N P * 129 \mathrm{Val}$ have been described by previous studies emphasizing on the PRNP biology relevant to the pathophysiology of the diseases. 
Table 2

Genotype frequency of M129V polymorphism of codon 129 in the prion gene $(P R N P)$ in various populations

\begin{tabular}{|c|c|c|c|c|c|c|c|}
\hline \multirow[t]{2}{*}{ Population } & \multirow[t]{2}{*}{ Total } & \multicolumn{3}{|c|}{ Genotype } & \multicolumn{2}{|c|}{ Allele } & \multirow[t]{2}{*}{ Reference } \\
\hline & & MM N(freq.) & MV N(freq.) & VV N(freq.) & $\mathrm{M}$ & $\mathrm{V}$ & \\
\hline Korean & 2,816 & $2,671(0.95)$ & $144(0.05)$ & $1(0.00)$ & 0.974 & 0.026 & This study \\
\hline Chinese (Hans) & 558 & $540(96.77)$ & $18(0.03)$ & 0 & 0.98 & 0.02 & [42] \\
\hline Taiwanese & 100 & $97(0.97)$ & $3(0.03)$ & 0 & 0.99 & 0.02 & [43] \\
\hline Korean & 236 & $223(0.95)$ & $13(0.05)$ & 0 & 0.97 & 0.03 & [44] \\
\hline Japanese & 466 & $436(0.94)$ & $30(0.06)$ & 0 & 0.97 & 0.03 & [45] \\
\hline Danish & 352 & $131(0.37)$ & $168(0.48)$ & $53(0.15)$ & 0.61 & 0.39 & [46] \\
\hline Finnish & 1957 & $969(0.49)$ & $818(0.42)$ & $170(0.09)$ & 0.70 & 0.30 & [47] \\
\hline Turkish & 100 & $57(0.57)$ & $34(0.34)$ & $9(0.09)$ & 0.74 & 0.26 & [48] \\
\hline Icelandic & 208 & $97(0.47)$ & $93(0.45)$ & $18(0.08)$ & 0.69 & 0.31 & [49] \\
\hline Slovakian & 613 & $295(0.48)$ & $265(0.43)$ & $53(0.09)$ & 0.70 & 0.30 & {$[50]$} \\
\hline Irish/N. Irish & 353 & $129(0.37)$ & $186(0.53)$ & $38(0.10)$ & 0.63 & 0.37 & [47] \\
\hline UK & 406 & $164(0.41)$ & $196(0.48)$ & $46(0.11)$ & 0.65 & 0.36 & [47] \\
\hline French & 161 & $63(0.39)$ & $82(0.51)$ & $16(0.10)$ & 0.65 & 0.35 & [47] \\
\hline Spanish & 546 & $231(0.42)$ & $239(0.44)$ & $76(0.14)$ & 0.64 & 0.36 & [47] \\
\hline Austrian & 300 & $129(0.43)$ & $146(0.49)$ & $25(0.08)$ & 0.67 & 0.33 & [39] \\
\hline Italian & 186 & $84(0.45)$ & $75(0.40)$ & $27(0.15)$ & 0.65 & 0.35 & [51] \\
\hline Cretan & 205 & $117(0.57)$ & $77(0.38)$ & $11(0.05)$ & 0.76 & 0.24 & [52] \\
\hline
\end{tabular}

$* P$-values of Chi-square tests compared to Korean population.

Table 3

Distribution and association of $P R N P$ M129V with neuropsychiatric diseases in various populations

\begin{tabular}{|c|c|c|c|c|c|c|c|c|c|}
\hline \multirow[t]{2}{*}{ Disease } & \multirow[t]{2}{*}{ Population } & \multicolumn{3}{|c|}{ Control } & \multicolumn{3}{|c|}{ Case } & \multirow[t]{2}{*}{ Association } & \multirow[t]{2}{*}{ Ref. } \\
\hline & & $\mathrm{N}$ & A (Met) & G (Val) & $\mathrm{N}$ & A (Met) & G (Val) & & \\
\hline Multiple sclerosis (MS) & Korean & 481 & 0.973 & 0.027 & 200 & 0.967 & 0.033 & NS & This \\
\hline Mild cognitive impairment (MCI) & & 481 & 0.973 & 0.027 & 320 & 0.978 & 0.022 & NS & Study \\
\hline Alcoholism & & 223 & 0.022 & 0.027 & 540 & 0.967 & 0.024 & NS & \\
\hline Schizophrenia & & 367 & 0.0971 & 0.029 & 348 & 0.973 & 0.027 & NS & \\
\hline \multirow[t]{11}{*}{ Alzheimer's disease (AD) } & Korean & 236 & 0.975 & 0.025 & 271 & 0.970 & 0.030 & NS & [44] \\
\hline & Korean & 217 & 0.972 & 0.028 & 297 & 0.963 & 0.037 & NS & [16] \\
\hline & Japanese & 466 & 0.970 & 0.030 & 548 & 0.965 & 0.035 & NS & [45] \\
\hline & Italian & 124 & 0.675 & 0.325 & 195 & 0.685 & 0.315 & NS & [53] \\
\hline & US(Caucasian) & 58 & 0.735 & 0.265 & 109 & 0.705 & 0.295 & NS & [18] \\
\hline & Italian & 318 & 0.675 & 0.325 & 258 & 0.675 & 0.325 & NS & \\
\hline & US & 415 & 0.710 & 0.290 & 281 & 0.710 & 0.290 & NS & [15] \\
\hline & Polish & 107 & 0.636 & 0.364 & 88 & 0.705 & 0.295 & $P=0.005$ & \\
\hline & Dutch & 282 & 0.650 & 0.350 & 44 & 0.625 & 0.375 & NS & [13] \\
\hline & Italian & 201 & 0.705 & 0.295 & 212 & 0.765 & 0.235 & NS & [55] \\
\hline & Spanish & 268 & 0.630 & 0.370 & 278 & 0.655 & 0.345 & NS & [17] \\
\hline \multirow[t]{2}{*}{ Alzheimer's disease (AD), early onset } & Polish & 194 & 0.645 & 0.355 & 53 & 0.680 & 0.320 & NS & [36] \\
\hline & & & & & 113 & 0.725 & 0.275 & $\mathrm{P}=0.05$ & \\
\hline \multirow[t]{2}{*}{ Schizophrenia } & German & 401 & 0.667 & 0.333 & 327 & 0.683 & 0.317 & NS & [31] \\
\hline & Spanish & 502 & 0.653 & 0.347 & 411 & 0.652 & 0.348 & NS & [56] \\
\hline Parkinson's disease (PD), & Caucasian & 125 & 0.612 & 0.388 & 54 & 0.667 & 0.333 & NS & [40] \\
\hline Multiple system atrophy (MSA) & & & & & 63 & 0.635 & 0.365 & NS & \\
\hline Temporal lobe epilepsy (TLE) & Italian & 272 & 0.719 & 0.280 & 289 & 0.660 & 0.340 & $\mathrm{P}=0.03$ & [38] \\
\hline \multirow[t]{3}{*}{ Idiopathic Parkinson's disease (IPD) } & Finnish & 131 & 0.676 & 0.324 & 142 & 0.669 & 0.331 & NS & [41] \\
\hline & Greek & 125 & 0.636 & 0.364 & 133 & 0.673 & 0.327 & NS & \\
\hline & US (Caucasian) & 142 & 0.676 & 0.324 & 125 & 0.696 & 0.304 & NS & \\
\hline Creutzfeldt - Jakob disease (CJD) & German & 722 & 0.640 & 0.360 & 582 & 0.780 & 0.220 & $\mathrm{P}<0.001$ & {$[22]$} \\
\hline
\end{tabular}

Despite that, there have been contradicting reports on the association of the variant with the mentioned diseases. This event demonstrates the need to further elucidate the involvement of the PRNP codon 129 polymorphism with the risk of MS and schizophrenia. In addition, since it has been known that polymorphisms of PRNP contribute to the genetic determinants of CJD and AD, it may also be rewarding to study alcoholism and MCI in this context considering that these conditions are often correlated with the latter diseases respectively.

In summary, we investigated the influence of 
$P R N P * 129$ Val in MS, MCI, alcoholism and schizophrenia in a Korean population $(n=2,479)$. We also presented a summary on previous genetic association studies of the PRNP variant. Despite the large sample sizes utilized in this study, statistical analyses did not reveal significant interaction between the PRNP polymorphism and MS, MCI, alcoholism and schizophrenia.

Our findings provide more evidence that $P R N P^{*}$ $129 \mathrm{Val}$ is not a genetic susceptibility factor for MS, MCI, alcoholism and schizophrenia in a Korean population. These results confirm some of the previous reports on this variant as presented in the literature. To our knowledge, few studies have extended the study of M129V polymorphism to MCI, and alcoholism.

\section{Conflicts of interest}

We have no conflicts of interest with this study.

\section{Acknowledgements}

This study was supported by a grant from the Korea Healthcare Technology R\&D Project, Ministry for Health, Welfare and Family Affairs, Republic of Korea (A080906).

\section{References}

[1] S.B. Prusiner, Prions, Proc Natl Acad Sci U S A 95 (1998), 13363-13383.

[2] P. Parchi, R. Castellani, S. Capellari, B. Ghetti, K. Young, S.G. Chen, M. Farlow, D.W. Dickson, A.A. Sima, J.Q. Trojanowski, R.B. Petersen and P. Gambetti, Molecular basis of phenotypic variability in sporadic Creutzfeldt-Jakob disease, Ann Neurol 39 (1996), 767-778

[3] C. Tranchant, L. Geranton, C. Guiraud-Chaumeil, M. Mohr and J.M. Warter, Basis of phenotypic variability in sporadic Creutzfeldt-Jakob disease, Neurology 52 (1999), 1244-1249.

[4] M.S. Palmer, A.J. Dryden, J.T. Hughes and J. Collinge, Homozygous prion protein genotype predisposes to sporadic Creutzfeldt-Jakob disease, Nature 352 (1991), 340-342.

[5] J. Collinge, M.S. Palmer and A.J. Dryden, Genetic predisposition to iatrogenic Creutzfeldt-Jakob disease, Lancet $\mathbf{3 3 7}$ (1991), 1441-1442.

[6] D. Goldgaber, L.G. Goldfarb, P. Brown, D.M. Asher, W.T. Brown, S. Lin, J.W. Teener, S.M. Feinstone, R. Rubenstein, R.J. Kascsak et al., Mutations in familial Creutzfeldt-Jakob disease and Gerstmann-Straussler-Scheinker's syndrome, Exp Neurol 106 (1989), 204-206.

[7] I. Zerr, A. Giese, O. Windl, S. Kropp, W. Schulz-Schaeffer, C. Riedemann, K. Skworc, M. Bodemer, H.A. Kretzschmar and S. Poser, Phenotypic variability in fatal familial insomnia (D178N-129M) genotype, Neurology 51 (1998), 1398-1405.
[8] O. Windl, A. Giese, W. Schulz-Schaeffer, I. Zerr, K. Skworc, S. Arendt, C. Oberdieck, M. Bodemer, S. Poser and H.A. Kretzschmar, Molecular genetics of human prion diseases in Germany, Hum Genet 105 (1999), 244-252.

[9] E. Grasbon-Frodl, R. Schmalzbauer, P. Weber, B. Krebs, O. Windl, I. Zerr and H.A. Kretzschmar, A novel three extrarepeat insertion in the prion protein gene (PRNP) in a patient with Creutzfeldt-Jakob disease, Neurogenetics 5 (2004), 249 250 .

[10] O.V. Chubukova, O.E. Mustafina, A.V. Chemeris, I.A. Tuktarova, K.Z. Bakhtiiarova, R.V. Magzhanov and M. Nikonorov $\mathrm{Iu}$, [Polymorphism of the prion protein PRNP gene and risk of multiple sclerosis development in ethnic Russians from Bashkortostan], Genetika 45 (2009), 691-699.

[11] S. Wojtowicz, Multiple sclerosis and prions, Med Hypotheses 40 (1993), 48-54.

[12] O. Stuve, C. Korth, P. Gabatto, E.M. Cameron, W. Hu, T.N. Eagar, N.L. Monson, E.M. Frohman, M.K. Racke, C.P. Zabetian and J.R. Oksenberg, Genetic polymorphism at codon 129 of the prion protein gene is not associated with multiple sclerosis, Arch Neurol 66 (2009), 280-281.

[13] B. Dermaut, E.A. Croes, R. Rademakers, M. Van den Broeck, M. Cruts, A. Hofman, C.M. van Duijn and C. Van Broeckhoven, PRNP Val129 homozygosity increases risk for earlyonset Alzheimer's disease, Ann Neurol 53 (2003), 409-412.

[14] M. Riemenschneider, N. Klopp, W. Xiang, S. Wagenpfeil, C. Vollmert, U. Muller, H. Forstl, T. Illig, H. Kretzschmar and A. Kurz, Prion protein codon 129 polymorphism and risk of Alzheimer disease, Neurology 63 (2004), 364-366.

[15] E. Golanska, K. Hulas-Bigoszewska, E. Rutkiewicz, M. Styczynska, B. Peplonska, M. Barcikowska, J. BratosiewiczWasik and P.P. Liberski, Polymorphisms within the prion (PrP) and prion-like protein (Doppel) genes in AD, Neurology 62 (2004), 313-315.

[16] K. Ahn, E. Kim, Y.A. Kwon, D.K. Kim, J.E. Lee and S.A. Jo, No association of prion protein gene polymorphisms with Alzheimer's disease in Korean population, Exp Mol Med 38 (2006), 727-731.

[17] O. Combarros, M. Sanchez-Guerra, J. Llorca, A. AlvarezArcaya, J. Berciano, N. Pena and C. Fernandez-Viadero, Polymorphism at codon 129 of the prion protein gene is not associated with sporadic AD, Neurology 55 (2000), 593-595.

[18] R. Del Bo, M. Scarlato, S. Ghezzi, F. Martinelli-Boneschi, C. Fenoglio, G. Galimberti, S. Galbiati, R. Virgilio, D. Galimberti, C. Ferrarese, E. Scarpini, N. Bresolin and G.P. Comi, Is M129V of PRNP gene associated with Alzheimer's disease? A case-control study and a meta-analysis, Neurobiol Aging $\mathbf{2 7}$ (2006), 770 e 771-770 e775.

[19] E. Teng, P.H. Lu and J.L. Cummings, Neuropsychiatric symptoms are associated with progression from mild cognitive impairment to Alzheimer's disease, Dement Geriatr Cogn Disord 24 (2007), 253-259.

[20] K. Palmer, A.K. Berger, R. Monastero, B. Winblad, L. Backman and L. Fratiglioni, Predictors of progression from mild cognitive impairment to Alzheimer disease, Neurology 68 (2007), 1596-1602.

[21] C. Berr, F. Richard, C. Dufouil, C. Amant, A. Alperovitch and P. Amouyel, Polymorphism of the prion protein is associated with cognitive impairment in the elderly: the EVA study, Neurology 51 (1998), 734-737.

[22] C. Vollmert, O. Windl, W. Xiang, A. Rosenberger, I. Zerr, H.E. Wichmann, H. Bickeboller, T. Illig and H.A. Kretzschmar, Significant association of a M129V independent polymorphism in the 5' UTR of the PRNP gene with sporadic Creutzfeldt-Jakob 
disease in a large German case-control study, J Med Genet $\mathbf{4 3}$ (2006), e53.

[23] J.D. Wadsworth, E.A. Asante, M. Desbruslais, J.M. Linehan, S. Joiner, I. Gowland, J. Welch, L. Stone, S.E. Lloyd, A.F. Hill, S. Brandner and J. Collinge, Human prion protein with valine 129 prevents expression of variant CJD phenotype, Science 306 (2004), 1793-1796.

[24] S. Gaytan-Garcia, J.J. Gilbert, J.H. Deck, and J.C. Kaufmann, Jakob-Creutzfeldt disease associated with Wernicke encephalopathy, Can J Neurol Sci 15 (1988), 156-160.

[25] A. Bertrand, J.P. Brandel, Y. Grignon, V. Sazdovitch, D. Seilhean, B. Faucheux, N. Privat, J.L. Brault, A. Vital, E. UroCoste, M. Pluot, F. Chapon, C.A. Maurage, F. Letournel, H. Vespignani, G. Place, C.F. Degos, K. Peoc'h, S. Haik and J.J. Hauw, Wernicke encephalopathy and Creutzfeldt-Jakob disease, J Neurol 256 (2009), 904-909.

[26] R.M. Murray, E. O'Callaghan, D.J. Castle and S.W. Lewis, A neurodevelopmental approach to the classification of schizophrenia, Schizophr Bull 18 (1992), 319-332.

[27] D.P. Salmon, L.J. Thal, N. Butters and W.C. Heindel, Longitudinal evaluation of dementia of the Alzheimer type: a comparison of 3 standardized mental status examinations, Neurology 40 (1990), 1225-1230

[28] P.D. Harvey, M. Parrella, L. White, R.C. Mohs, M. Davidson and K.L. Davis, Convergence of cognitive and adaptive decline in late-life schizophrenia, Schizophr Res 35 (1999), 77-84.

[29] D. Rujescu, E.M. Meisenzahl, I. Giegling, A. Kirner, G. Leinsinger, U. Hegerl, K. Hahn and H.J. Moller, Methionine homozygosity at codon 129 in the prion protein is associated with white matter reduction and enlargement of CSF compartments in healthy volunteers and schizophrenic patients, Neuroimage 15 (2002), 200-206.

[30] K.L. Davis, D.G. Stewart, J.I. Friedman, M. Buchsbaum, P.D. Harvey, P.R. Hof, J. Buxbaum and V. Haroutunian, White matter changes in schizophrenia: evidence for myelin-related dysfunction, Arch Gen Psychiatry 60 (2003), 443-456.

[31] D. Rujescu, I. Giegling, A. Gietl, C. Gonnermann, A. Kirner, H.J. Moller and N. Dahmen, Association study of a SNP coding for a M129V substitution in the prion protein in schizophrenia, Schizophr Res 62 (2003), 289-291.

[32] H.-Y.P. Ho Jin Kim, Inho Jo, Eunkyung Kim, Kwang-Soo Lee, Kwang-Kuk Kim, Byung-Ok Choi, Inho Jo, Joon Seol Bae, Soo Ok Lee, Hyun Sub Cheong and Hyoung Doo Shin, Common CYP7A1 Polymorphism Associated with Risk of Neuromyelitis Optica in a Korean Population From GenomeWide Association Study, (2009).

[33] D.J. Kim, I.G. Choi, B.L. Park, B.C. Lee, B.J. Ham, S. Yoon, J.S. Bae, H.S. Cheong and H.D. Shin, Major genetic components underlying alcoholism in Korean population, $\mathrm{Hum} \mathrm{Mol}$ Genet 17 (2008), 854-858.

[34] H.D. Shin, B.L. Park, E.M. Kim, S.O. Lee, H.S. Cheong, C.H. Lee, S.G. Kim, J.W. Sohn, C.S. Park, J.W. Kim, B.H. Kim, I.Y. Kim, I.G. Choi and S.I. Woo, Association analysis of G72/G30 polymorphisms with schizophrenia in the Korean population, Schizophr Res 96 (2007), 119-124.

[35] K.J. Livak, Allelic discrimination using fluorogenic probes and the 5' nuclease assay, Genet Anal 14 (1999), 143-149.

[36] M. Gacia, K. Safranow, M. Styczynska, K. Jakubowska, B. Peplonska, M. Chodakowska-Zebrowska, I. Przekop, A. Slowik, E. Golanska, K. Hulas-Bigoszewska, D. Chlubek, D. Religa, C. Zekanowski and M. Barcikowska, Prion protein gene M129 allele is a risk factor for Alzheimer's disease, $J$ Neural Transm 113 (2006), 1747-1751.
[37] D. Rujescu, A.M. Hartmann, C. Gonnermann, H.J. Moller and I. Giegling, M129V variation in the prion protein may influence cognitive performance, Mol Psychiatry 8 (2003), 937-941.

[38] A. Labate, I. Manna, A. Gambardella, E. Le Piane, A. La Russa, F. Condino, R. Cittadella, U. Aguglia and A. Quattrone, Association between the M129V variant allele of PRNP gene and mild temporal lobe epilepsy in women, Neurosci Lett $\mathbf{4 2 1}$ (2007), 1-4.

[39] E.A. Croes, B. Dermaut, J.J. Houwing-Duistermaat, M. Van den Broeck, M. Cruts, M.M. Breteler, A. Hofman, C. van Broeckhoven and C.M. van Duijn, Early cognitive decline is associated with prion protein codon 129 polymorphism, Ann Neurol 54 (2003), 275-276.

[40] C. Shibao, E.M. Garland, A. Gamboa, C.L. Vnencak-Jones, M. Van Woeltz, J.L. Haines, C. Yu and I. Biaggioni, PRNP M129V homozygosity in multiple system atrophy vs. Parkinson's disease, Clin Auton Res 18 (2008), 13-19.

[41] S.W. Scholz, G. Xiromerisiou, H.C. Fung, J. Eerola, O. Hellstrom, A. Papadimitriou, G.M. Hadjigeorgiou, P.J. Tienari, H.H. Fernandez, R. Mandel, M.S. Okun, K. Gwinn-Hardy and A.B. Singleton, The human prion gene M129V polymorphism is not associated with idiopathic Parkinson's disease in three distinct populations, Neurosci Lett 395 (2006), 227-229.

[42] X. Wang, W. Sun, X. Zhu, X. Wu, L. Li, S. Zhu, T. Du, Y. Liu, N. Niu, Y. Wang and Y. Liu, M129V polymorphism in the prion protein gene is not associated with mesial temporal lobe epilepsy in a Han Chinese population, Eur J Neurol 15 (2008), 827-830

[43] M.T. Tsai, Y.C. Su, Y.H. Chen and C.H. Chen, Lack of evidence to support the association of the human prion gene with schizophrenia, Mol Psychiatry 6 (2001), 74-78.

[44] B.H. Jeong, K.H. Lee, Y.E. Jeong, K.A. Hwang, Y.J. Lee, R.I. Carp, Y.R. Ju and Y.S. Kim, Polymorphisms at codons 129 and 219 of the prion protein gene (PRNP) are not associated with sporadic Alzheimer's disease in the Korean population, Eur J Neurol 14 (2007), 621-626.

[45] T. Ohkubo, Y. Sakasegawa, T. Asada, T. Kinoshita, Y. Goto, H. Kimura, H. Mizusawa, N.S. Hachiya and K. Kaneko, Absence of association between codon 129/219 polymorphisms of the prion protein gene and Alzheimer's disease in Japan, Ann Neurol 54 (2003), 553-554; author reply 555.

[46] H. Dyrbye, H. Broholm, M.H. Dziegiel and H. Laursen, The M129V polymorphism of codon 129 in the prion gene (PRNP) in the Danish population, Eur J Epidemiol 23 (2008), 23-27.

[47] M.H. Nurmi, M. Bishop, L. Strain, F. Brett, C. McGuigan, M. Hutchison, M. Farrell, R. Tilvis, S. Erkkila, O. Simell, R. Knight, and M. Haltia, The normal population distribution of PRNP codon 129 polymorphism Acta Neurol Scand $\mathbf{1 0 8}$ (2003), 374-378.

[48] N. Erginel-Unaltuna, K. Peoc'h, E. Komurcu, T.T. Acuner, H. Issever and J.L. Laplanche, Distribution of the M129V polymorphism of the prion protein gene in a Turkish population suggests a high risk for Creutzfeldt-Jakob disease, Eur J Hum Genet 9 (2001), 965-968.

[49] G. Georgsson, T. Tryggvason, A.D. Jonasdottir, S. Gudmundsson and S. Thorgeirsdottir, Polymorphism of PRNP codons in the normal Icelandic population, Acta Neurol Scand $\mathbf{1 1 3}$ (2006), 419-425.

[50] E. Mitrova, V. Mayer, V. Jovankovicova, D. Slivarichova and L. Wsolova, Creutzfeldt-Jakob disease risk and PRNP codon 129 polymorphism: necessity to revalue current data, Eur J Neurol 12 (2005), 998-1001. 
[51] M. Salvatore, M. Genuardi, R. Petraroli, C. Masullo, M. D'Alessandro and M. Pocchiari, Polymorphisms of the prion protein gene in Italian patients with Creutzfeldt-Jakob disease, Hum Genet 94 (1994), 375-379.

[52] A. Plaitakis, A.K. Viskadouraki, M. Tzagournissakis, I. Zaganas, S. Verghese-Nikolakaki, V. Karagiorgis, I. Panagiotides, C. Kilindireas, E. Patsouris, C. Haberler, H. Budka and T. Sklaviadis, Increased incidence of sporadic CreutzfeldtJakob disease on the island of Crete associated with a high rate of PRNP 129-methionine homozygosity in the local population, Ann Neurol 50 (2001), 227-233.

[53] A. Poleggi, A. Bizzarro, A. Acciarri, P. Antuono, S. Bagnoli, E. Cellini, G.D. Forno, C. Giannattasio, A. Lauria, M.G. Matera, B. Nacmias, M. Puopolo, D. Seripa, S. Sorbi, D.R. Wekstein, M. Pocchiari and C. Masullo, Codon 129 polymorphism of prion protein gene in sporadic Alzheimer's disease, Eur J
Neurol 15 (2008), 173-178.

[54] X. Li, L.P. Rowland, H. Mitsumoto, S. Przedborski, T.D. Bird, G.D. Schellenberg, E. Peskind, N. Johnson, T. Siddique, M.M. Mesulam, S. Weintraub and J.A. Mastrianni, Prion protein codon 129 genotype prevalence is altered in primary progressive aphasia, Ann Neurol 58 (2005), 858-864.

[55] V.M. Casadei, C. Ferri, E. Calabrese, L.M. Grimaldi, M. Franceschi, F. Veglia, F. Licastro and C. Mariani, Prion protein gene polymorphism and Alzheimer's disease: one modulatory trait of cognitive decline?, J Neurol Neurosurg Psychiatry 71 (2001), 279-280.

[56] L. Martorell, J. Valero, B. Mulet, A. Gutierrez-Zotes, M.J. Cortes, M. Jariod, M. Perez, A. Labad and E. Vilella, M129V variation in the prion protein gene and psychotic disorders: relationship to neuropsychological and psychopathological measures, J Psychiatr Res 41 (2007), 885-892. 


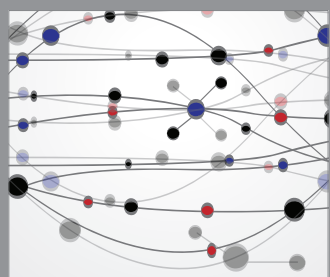

The Scientific World Journal
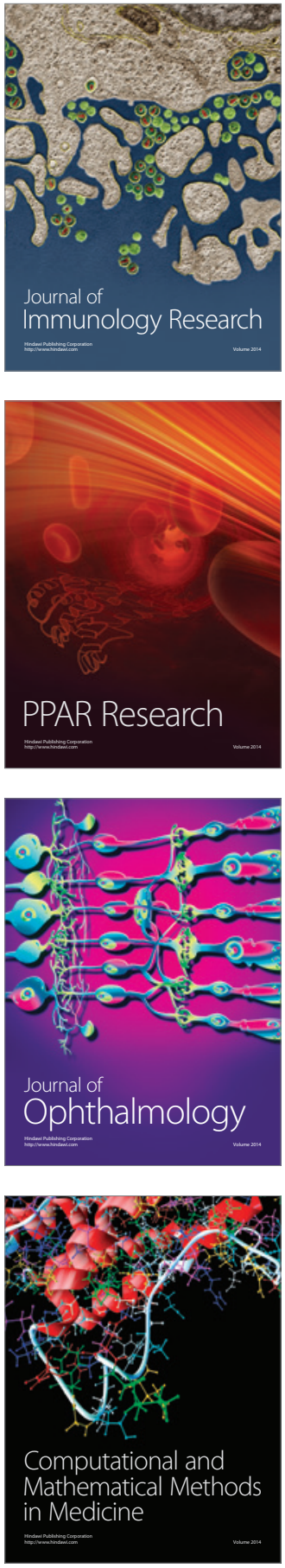

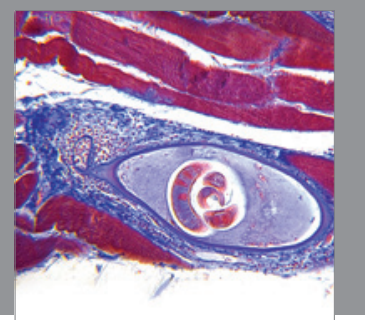

Gastroenterology

Research and Practice
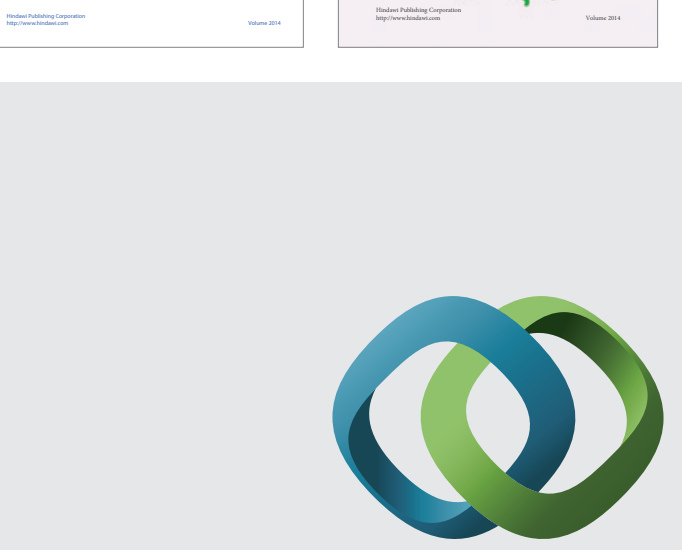

\section{Hindawi}

Submit your manuscripts at

http://www.hindawi.com
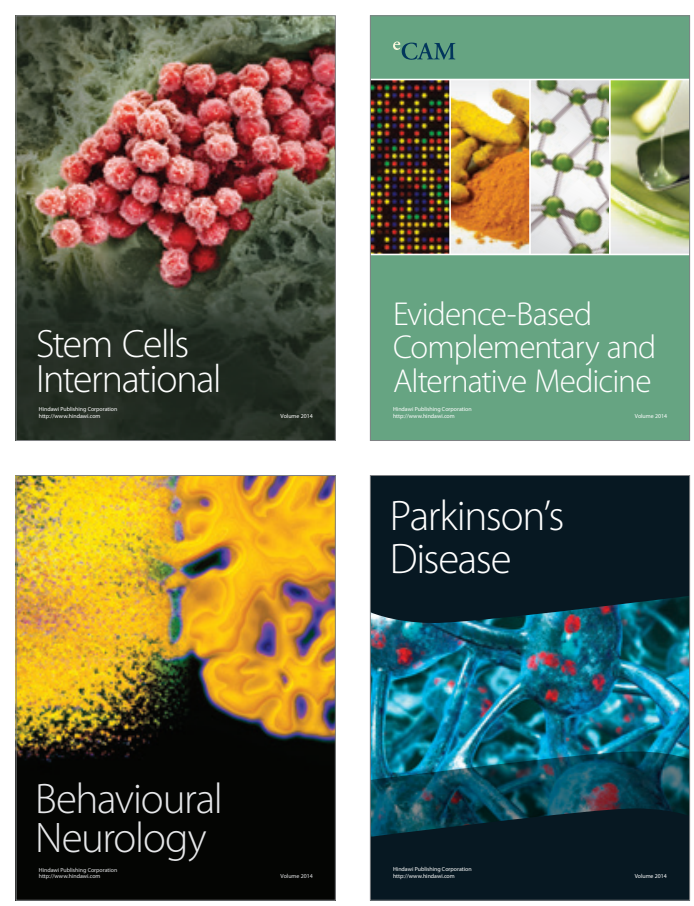

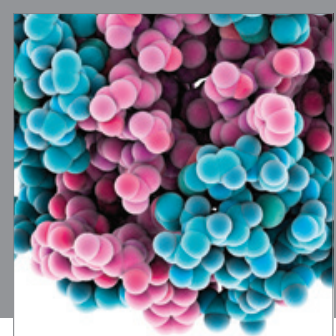

Journal of
Diabetes Research

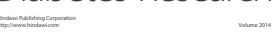

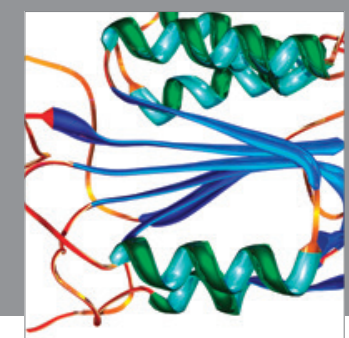

Disease Markers
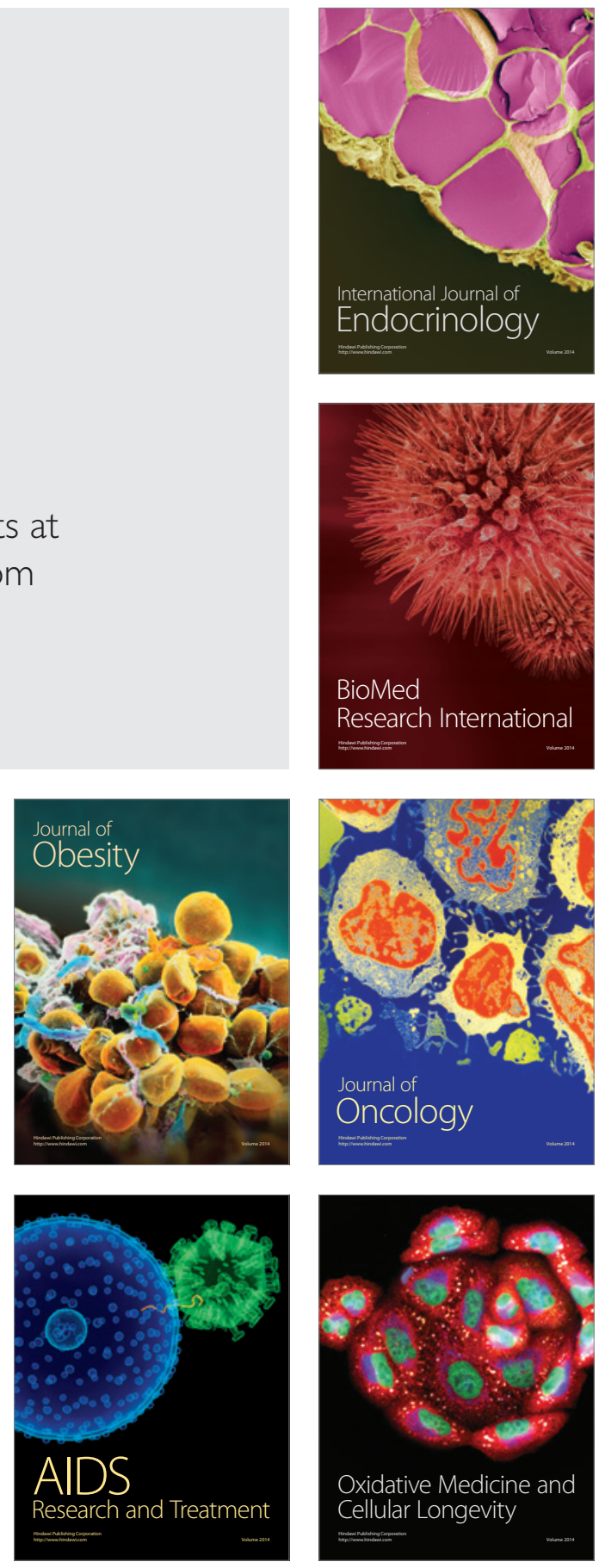